Published in final edited form as:

Popul Res Policy Rev. 2004 June ; 23(3): 187-218.

\title{
NATURALIZATION OF U.S. IMMIGRANTS:
}

\section{HIGHLIGHTS FROM TEN COUNTRIES}

\author{
Karen A. Woodrow-Lafield, \\ University of Notre Dame \\ Xiaohe Xu, \\ Mississippi State University \\ Thomas Kersen, and \\ Mississippi State University \\ Bunnak Poch \\ University of Chicago
}

\begin{abstract}
The saga of U.S. immigrant naturalization is merely sketched for about 25 million immigrants entered in three decades of renewed immigration. This study documents naturalization outcomes for immigrants from ten major countries of origin, using administrative records on immigrants and naturalizations. Following the 1978-1987 admission cohorts for the first decade or more of permanent residence, this study finds significant covariate effects on the timing of naturalization by origin, mode of entry, and immigrant visa class, net other influences of demographic and background characteristics. Immigrants from the Philippines, Vietnam, and China, naturalized more quickly than immigrants from India, Korea, Cuba, Colombia, Jamaica, the Dominican Republic, and Mexico. Those who adjusted from statuses as nonimmigrants, refugees, or asylees became naturalized citizens more quickly. Those immigrants with employment-sponsorship naturalized faster than familysponsored immigrants. Spouses of citizens, spouses of permanent residents, spouses of siblings of citizens, and spouses of sons and daughters of citizens naturalized faster than some other immigrants. Gender was not significant in the multivariate analysis but further research will more fully explore sex-specific variation in the timing of naturalization given likely variation in women's representation by origin and admission categories.
\end{abstract}

\section{Keywords \\ Immigrants; integration; naturalization; origins; sponsorship}

\section{INTRODUCTION}

The new immigration of three decades is distinctive as many of these immigrants, Latin American and Asian in origin, are settling in geographic clusters and maintaining cultural and linguistic communities. The sustained pace of high immigration influences U.S. population growth and alters the ethnicity nationally and locally. The past model of European immigration and assimilation is unlikely to describe the trajectories of new immigrants from a historical perspective, because the continuing immigration implies multiple tiers of new immigrants or aliens, naturalized citizens, first generation and second generation natives, ancestries, social 
class, immigrant enclaves, and social inequalities (Massey 1995). Studies have intensified as to immigration's demographic, economic, and social dimensions for contemporary and future America (Hirschman, Kasinitz, \& DeWind 1999; Smith \& Edmonston 1997; Binational Migration Study 1997; Espenshade 1994).

Much work remains in describing, conceptualizing, theorizing, and explaining immigrant experiences, such as becoming a U.S. naturalized citizen. In a reversal of the six-decade pattern in the 1930-1980 censuses, the non-naturalized population was greater than the naturalized citizen population in 1990 and 2000 (Gibson \& Lennon 1999; Schmidley \& Gibson 1999; U.S. Bureau of the Census 1975). Compositional factors may partly explain this differential, as unauthorized residents, formerly unauthorized residents who gained lawful status under the Immigration Reform and Control Act of 1986 (IRCA), and many immigrants could not have naturalized in the 1980s. Without the presence of generally legalized immigrants in the 1980 and 1990 censuses, changing composition on duration of residence accounted for more than one-half of the difference in proportion naturalized, and less than one-half was due to changing propensity (Woodrow-Lafield 1998). The unauthorized population remained substantial in 1990 (Woodrow 1992) and in 2000 (Bean, Corona, Tuirán, Woodrow-Lafield \& Van Hook 2001; Bean, Van Hook \& Woodrow-Lafield 2001). Naturalization and political incorporation of immigrants merit consideration as much as educational and economic participation of immigrants (Tienda 2002).

Immigrants are persons admitted as lawful permanent residents under the Immigration and Nationality Act (INA) through either the immigration preference system for which admission categories are numerically limited or provisions for numerically exempt immigration. A crosssectional correlation between longer residence and naturalization is well documented (De Sipio 1987). Most are not immediately eligible to naturalize, and must have five years of continuous lawful permanent residence. That time allows for acquisition of ability in speaking, reading, and writing English, knowledge of the U.S. government and U.S. history, as well as building a work history and interest in naturalizing. This dominance of duration effect is likely overstated, as may be also socioeconomic effects, because individuals may have departed after redefining their stays as temporary rather than permanent, perhaps due to English difficulties or unemployment (Lindstrom \& Massey 1994). This event may signify commitment, although some may regard U.S. citizenship as merely a convenience or a complement to other citizenship or nationality rights.

Immigrants are a heterogeneous group on visa class of admission and this subsumes other important individual characteristics. Mode of entry as either newly arriving or as adjusting from a nonimmigrant category is understudied and poorly measured. The volume of nonimmigrant arrivals, temporary travelers for business and pleasure, foreign students, and special workers, rose markedly in the 1980s and 1990s. Nonimmigrant adjustments to permanent residence comprise greater shares of annual immigrant admissions. Among immigrants "arriving," many have a previous nonimmigrant stay that is not apparent in official statistics (Massey \& Malone 2003; Jasso, Massey, Rosenzweig, \& Smith 2000a; WoodrowLafield 1998; Kraly \& Warren 1991, 1992). Arriving and adjusting immigrants may differ on adaptation skills for living in the United States, given lengthy durations of temporary residence.

Origin differentials on having naturalized appeared for long-term residents in the 1990 census with higher levels for Asians (76 percent) and Africans (65 percent) than Europeans or Canadians (53 percent) or non-Mexican Latin Americans ( 50 percent), and lower naturalization for Mexicans (31 percent) (Chiswick \& Sullivan 1995:232). These differentials resemble other studies (Schmidley 2001; De Sipio and de la Garza 1998; Bean, Chapa, Berg, \& Sowards 1994; Woodrow 1992). The majority of foreign-born persons here for two decades had become naturalized citizens in the 2000 census, with 86 percent of Asian origin persons naturalized, 
and similar levels for European ( 81 percent), African ( 80 percent), Caribbean ( 80 percent), and South American (77 percent). Among long-resident Mexicans in 2000, 52 percent were naturalized. From administrative sources, formerly from the U.S. Immigration and Naturalization Service (INS) and now from the Office of Immigration Statistics in the Department of Homeland Security, naturalization levels vary by duration of residence, origin, and immigrant visa class. Official reports for those naturalizing annually show Asians as having fewer years of residence than North Americans (INS 1998). Considering immigrant visa class, professional or highly skilled immigrants and refugees have shown higher naturalization, and parents of citizens have apparently naturalized less than other categories of relatives (INS 1998). Immigrant visa classes are differentially represented among origin groups with large shares of managerial and professional workers and refugees for Asian immigrants.

This study examines the roles of origin, mode of entry, and immigrant visa class in immigrants' transition to naturalization over the first decade or more of lawful permanent residence. The next section reviews prior research and presents hypotheses as to origin, immigrant visa class, and mode of entry in the process of naturalizing. Following that review, the Immigration-toNaturalization Project (INP) dataset is described, immigrant records for all admissions in 1978-1987 linked with naturalization records as of 1996. The modeling strategy is then discussed, Cox regression hazards models of naturalizing over duration of residence. These initial results on the influence of origin and admission circumstances for becoming naturalized give new insights from the vantage point of multiple cohorts rather than a single cohort.

\section{PRIOR RESEARCH}

National origin is one type of identity (Rumbaut 1995) with the gendered and hyphenated process of ethnic identification evolving through language, discrimination, and naturalization in America. Some immigrants may be very decided on the United States as their residence and naturalize quickly whereas others do so more gradually. Immigrants from bordering countries may be less likely to settle permanently or to naturalize simply because they can so easily travel to and from origin communities in Mexico or Canada (Liang 1994; Massey, Alarcon, Durand, \& Gonzalez 1987). Those from a more distant land, e.g., in Asia, may be more permanent and likely to adopt the nation (Zelinsky 1971), although ease of travel, communications, and financial transactions diminish the return migration costs.

Whether an immigrant must relinquish origin citizenship may be an undeniable cost of becoming a U.S. citizen (Yang 1994). The United States has not enforced the requirement of renunciation of original nationality, and several nations, including Canada, Chile, El Salvador, Panama, Vietnam, the Philippines, France, Italy, Ireland, and Jamaica, have long permitted their citizens to retain original citizenship. Other countries are clearly against duality on citizenship, such as Cuba, Guatemala, China, and Korea (Renshon 2001; Spiro 1999). The value of immigrant remittances is substantial and a number of nations, e.g., Brazil, Colombia, Ecuador, Mexico, and the Dominican Republic, changed laws in the 1990s to recognize dual citizenship and retention of nationality rights (Jones-Correa 2001; Weintraub 1998; Smith \& Edmonston 1997; Woodrow-Lafield 1995) and dispel their citizens' concerns of losing home ties that may have been barriers to naturalizing in the United States. Origin country may reflect cultural influences related to gender roles, marriage, family, and work.

Immigrants have varying motivations for migrating, and they possess varying amounts of human capital or potential in acculturation (formal education, language capability, labor skills, work experience, and beliefs about family, work, religion, and daily life) associated with success, staying, and naturalizing. Neoclassical reasoning is at the root of many immigrants' migration decision as there may be poor prospects for economic livelihood in the origin community. Individuals' decisionmaking to maximize expected income through migration 
may be in terms of the household or individuals from the greater household remaining in the origin country (Massey, Arango, Hugo, Kouaouci, Pellegrino, \& Taylor. 1998; Tilly 1990). Strong evidence suggests some positive selectivity of immigrants from origin countries on skills, temperament, or vigor, but that association is not fixed and depends on contexts, migration dynamics, and social networks (Bustamante, Jasso, Taylor, \& Trigueros 1998).

The circumstances of lawful admission for permanent residence pursuant to the Immigration and Nationality Act result in a multidimensional heterogeneity added to typical dimensions of demographic characteristics, socioeconomic characteristics, and individual attitudes. An individual immigrant may be (1) an original immigrant or non-original immigrant; (2) a newly arriving immigrant or adjusting immigrant; (3) a principal beneficiary immigrant or secondary beneficiary immigrant; (4) a family-sponsored immigrant or immediate relative of a citizen, an employment-sponsored immigrant, or another type of immigrant. The original immigrant may or may not fit the stereotype of a person facing alone the challenges of a new land, because friends or extended family members may have already immigrated. Newly arriving immigrants and adjusting immigrants differ on adaptation measures (Kanjanapan 1995). In addition, adjusting immigrants are already selected from the larger pool of nonimmigrants, primarily students, temporary workers, visitors for business or pleasure, and exchange visitors, in having redefined their duration of residence from temporary to permanent.

Within most preference categories, those having a consanguineal or affineal tie to the principal beneficiary, whose consanguineal or affineal tie or employment eligibility gives the visa entitlement, may accompany and immigrate as secondary beneficiaries. The principal beneficiary is more likely to have a social or employment network in the United States, and accompanying secondary beneficiaries, spouses and children, vary as to dependency in social, linguistic, and financial ways.

The majority of immigrants have been under family-sponsored preference categories or as immediate relatives of U.S. citizens, although others come under employment-sponsored immigrants, under humanitarian criteria, or other categories. The unmarried and married sons and daughters of citizens, with spouses and children, or the siblings of citizens, with spouses and children, may be granted numerically limited visas. The immediate relatives of citizens may be sponsored without limitation. Permanent residents may only apply for numerically limited visas for spouses and children. Alternatively, individuals may be sponsored by employers needing their skills or capabilities or by the U.S. government deeming their importance in the labor market, again subject to limitation. Western Hemisphere immigration was less restrained until the preference system was extended to Western Hemisphere countries with annual immigrant visas numerically limited to 20,000 per country under the Immigration and Nationality Act Amendments of October 20, 1976. Another major change was placement of both Eastern and Western Hemisphere countries under a single, worldwide limit in 1978 legislation. The volume of migration of Western Hemisphere spouses and children suggests that Western Hemisphere immigrants sought to obtain the more expansive sponsorship rights of U.S. citizens for in the 1980s.

The third major category is immigrants under humanitarian criteria. Refugees and asylees are individuals who have demonstrated, with respect to their origin countries, that they are "unable or unwilling to return to that country because of persecution or a well-founded fear of persecution, based on the alien's race, religion, nationality, membership in a particular social group, or political opinion" according to the 1951 Geneva convention. Persons arriving as refugees in the 1970s were in a state of limbo as to permanence. The Refugee Resettlement Act of 1980 established clear criteria and procedures for admission of refugees to lawful permanent residence. Furthermore, satisfying the residence requirement was based on actual 
date of arrival. (A fourth major category, diversity-based criteria, was specified in the Immigration Act of 1990 applicable for the most recent immigrants.)

Origin is hypothesized as differentiating among immigrants' timing and completion of naturalization because origin is treated in a general sense, as an extension of the multiple ways in which immigrants from a nation are engaged in changing definition of stays as permanent in duration (Roberts 1995). At this point, the approach is not one of endeavoring to incorporate the complexities of origin and destination factors across time. In Jasso and Rosenzweig (1986, 1990), analyzing Eastern or Western Hemisphere origins showed higher naturalization for Eastern Hemisphere immigrants, as also found for Asian origins (Rytina 1998). Differences were observed among origin country groups as well and the proportions naturalized after a decade were higher for Africans, Asians, Europeans, and Oceanians than for Canadians, Caribbeans, and Latin Americans. Contextual origin variables were found influential (Jasso and Rosenzweig 1990). Immigrants from countries with high gross national product per capita (GNP) were significantly less likely to have naturalized. Immigrants from countries with Voice of America broadcasts in native language were more likely to have naturalized, as were also those from a country with English as an official language (Rytina 1998; Jasso \& Rosenzweig 1986).

Family-sponsored immigrants and immediate relatives join kin networks and potentially have access to social and financial support. Additionally, certain other family-sponsored immigrants, spouses of permanent residents and citizens and spouses of siblings or married sons or daughters of citizens, and immediate relative spouses may have few family members here and may seek to naturalize for the family reunification benefits (Jasso \& Rosenzweig 1986, 1990). Aliens may have naturalized to petition for their adult sons and daughters under $1^{\text {st }}$ preference rather than $2^{\text {nd }}$ for which visas were more limited. Already advantaged on human capital measures, employment-sponsored immigrants quickly gained a labor force attachment or niche and were more likely to make the transition to naturalized citizen (Jasso \& Rosenzweig 1986, 1990), plus that credential allows access to certain occupations, such as those requiring citizenship or those requiring security clearances, and facilitates international travel crucial for career advancement for some professionals. Another study by Rytina (1998) supported an association of employment sponsorship, especially professional categories, on higher probabilities of naturalizing.

From Jasso and Rosenzweig (1986), within gender, immigrants under different visa categories were differentially likely to have naturalized. Male immigrants as spouses of permanent residents or refugees had the highest probabilities of having naturalized among men, and women immigrants who were spouses of siblings of citizens or labor-certified immigrants had the highest among women. Women from the Western Hemisphere seemed to have lesser likelihood of naturalizing. The accompanying nature of women's immigration might diminish their assertiveness in naturalizing except for those possessing labor skills or joining family networks. Among men immigrating from Eastern Hemisphere countries, either as husbands of U.S. citizens and nonimmigrant adjustees or those with employment-sponsorship visas, those more likely to naturalize were those advancing occupationally over 1977-1990 independently of any initial advantage from employment sponsorship (Jasso \& Rosenzweig 1995). The role of occupational change over time for women's naturalizing is as yet unexplored.

Closer scrutiny on individual origin groups within the heterogeneous Western Hemisphere or the Eastern Hemisphere category has delineated differences in naturalizing. Origin may be an attribute that denotes reasons for migrating, e.g., economic for Mexicans and political for Cubans, that are associated with staying and naturalizing (Aguirre and Saenz 2002; Liang 1994). Analyzing six origins for one immigrant cohort, by age and sex, the timing of naturalization (Liang 1994) varied among Chinese, Canadians, Koreans, Colombians, Cubans, 
and Mexicans. Mexican immigrants had lower probabilities of naturalizing at first, but the probabilities were highest in the 12th to 17th years after immigrating. Although Mexican origin immigrants appear to naturalize more slowly than others, Mexicans have higher naturalization than Germans and Canadians (Bustamante et al. 1998). Although Aguirre and Saenz (2002) observed higher citizenship for Cubans than Mexicans, the relationship between ethnic identity and naturalizing was mitigated by several factors, including arrival date and post-immigration experiences.

A general hypothesis is that immigrants from Eastern Hemisphere countries may naturalize more quickly given the greater distance and costs in coming to the United States. Immigrants from Western Hemisphere countries may naturalize less quickly as the settlement process is extended over time. Immigrants of origins for which dual nationality is an option are expected to show higher naturalization although married couples may prefer to have a citizenship diversification portfolio (Jasso 1997). Among Western origins, differences in naturalizing are expected given different migration contexts of source countries. Immigrants whose motivations were related to short-term economic benefits would be less likely to naturalize than those whose motivations derived from fears of persecution or alienation from a political regime.

Mode of entry, prior social contact or U.S. experience, may be associated with naturalization. Specifically, those immigrants identified as having been a temporary resident would be more likely to naturalize. These individuals are positively selected on commitment to the United States, and their major activities, such as students or workers may have prepared them to fulfill requirements for naturalization.

A third set of hypotheses concerns naturalization outcomes and admission criteria related to human capital or social capital. Immigrants already having direct or secondary attachment to the U.S. labor force are expected to naturalize more quickly, whether to strengthen their attachment or as a consequence of human capital (Jasso \& Rosenzweig 1986, 1990). Immigrants with fewer family members in the United States, the spouses of aliens and citizens, and the spouses of siblings and sons or daughters, are expected to naturalize more quickly than immigrants reuniting with consanguineal family members, such as sons and daughters of aliens and citizens, or siblings and parents of citizens, because their family reunification needs are greater (Jasso \& Rosenzweig 1986, 1990). Spouses also have a special endowment in a shorter residency requirement and have a potential source of social capital in having this close relative who may know of the importance and procedures for applying for citizenship. The presence of children might also promote naturalizing as helping to integrate parents within communities and social institutions (Astone, Nathanson, Schoen \& Kim 1999). Finally, a gender hypothesis is that males may be likely to naturalize more quickly than females given the greater initiating role in sponsoring family members as immigrants as Jasso and Rosenzweig (1990) noted with 1980 census data. Other evidence suggests Latin American women may choose to naturalize for gaining civic participation as they decide more quickly on U.S. settlement for their families (Jones-Correa 1998). These hypotheses may not be inconsistent because return migration of males would inflate the census naturalization rates.

\section{DATA AND METHODOLOGY}

Although tracking cohorts as to naturalization was regarded as promising (Levine, Hill, \& Warren 1985, p. 49), the Jasso and Rosenzweig study $(1986,1990)$ based on the 1971 cohort was singular until creation of the 1977 and 1982 Immigrant-Naturalization Cohorts (INS Statistics Office, undated), each for immigrants 16 years and older at admission. This section describes creation of a comprehensive dataset on immigrants' naturalization and technical details and sets forth the hazards models to explore covariates in naturalizing. (See also Woodrow-Lafield, Xu, Kersen, and Poch 2000. 
The basic data are the immigrant and naturalization administrative records with encrypted identifiers, linked within the Immigration-to-Naturalization Project (INP) initiated in 1999. For this project, appropriate measures safeguarded against data disclosure, although names, certainly the most sensitive information, were not provided. ${ }^{1}$ The immigrant microdata for the project were similar to the annual immigrant public use files available from the National Technical Information Service (NTIS) or the Inter-University Consortium for Political and Social Research (ICPSR) at the University of Michigan. Immigrant records include age, sex, country of birth, class of admission, marital status, nonimmigrant class for adjustments, occupation reported, and month and year of immigrant admission, drawn from visa application forms, that is, the State Department's OF-155 Immigrant Visa and Alien Registration and the I-485 Application to Register Permanent Residence or to Adjust Status. Naturalization records also include age, sex, marital status, country of birth, the year of admission as permanent resident, current occupation, month and year of naturalization, and provisions under which naturalized. The data are based primarily on the N-400 form for Application to File Petition for Naturalization completed by persons 18 years and over (and N-402 form on Behalf of Child). (Until 1998 the data files also included the N-600 forms for the Application for Certificate of Citizenship (or N-643 on Behalf of an Adopted Child).)

In dealing with admission categories and origin countries across years of immigrant data, the work of Greenwood and Ziel (1997) was helpful, as were data documentation and various editions of Statistical Yearbook. Some researchers have used only one annual dataset (Tyree \& Donato 1985; Donato 1992) or two or three years for longitudinal comparisons or greater numbers (Kanjanapan 1995; De Jong \& Blair 1994). Studies using multiple years include Houston, Kramer, and Barrett (1984), Greenwood and McDowell (1999), Greenwood, McDowell, \& Zahniser (1999), Greenwood, McDowell, and Trabka (1991), Salvo and Ortiz (1992), Lobo and Salvo (1998, 2000), Singer, Friedman, Cheung, and Price (2000), Bagchi (2001), and Jasso, Rosenzweig, and Smith (1998). Researchers used multiple datasets in estimating the lawfully resident foreign-born population over 1980-2001 and quantifying net unauthorized migration (Bean et al. 2001; Bean et al. 2001; Bean, Corona, Tuirán, \& WoodrowLafield 1998; Woodrow-Lafield 1998; Woodrow and Passel 1990).

The data have the typical limitations of administrative records. Some variables (e.g., sex, occupation, nonimmigrant class and year of entry) are missing for 1980-1983 because primary data were lost, and an alternative database, based on I-551 forms for alien registration receipt cards, included more limited detail. Production of microdata files in the 1970s was poorly documented until the mid-1980s and counts from statistical systems were apparently reconciled with performance analysis systems by case duplication within preference category (Wachter 1985). The revised 1979 immigrants microdata set has fewer immigrant records than the 1979 Statistical Yearbook because 64,000 duplicate cases were deleted. This revision introduced little bias (Greenwood, McDowell \& Trabka 1991; Greenwood \& McDowell 1999).

Naturalizations microdata files were sometimes incomplete (Passel, Clark \& Fix 1997; Salvo \& Ortiz 1992), such as in 1994 when about 23,000 cases were omitted, primarily from San Francisco, Chicago, and Houston (Jasso \& Rosenzweig 1990: 379) and in 1996 when there was some missing data for approximately 100,000 naturalization cases, e.g., marital status, occupation, naturalization provision, country of former allegiance, residence, and sex (about one-third). Naturalization records are particularly incomplete for immigrants under 16 years

\footnotetext{
${ }^{1}$ This data sharing is easier among federal agencies (GAO 2001), e.g., INS provided naturalizations records to the U.S. General Accounting Office for a study of public assistance utilization (GAO 1999). That report's appendix describes construction of the database containing, after elimination of duplicate records and all prior to 1970 due to data quality, 3.6 million individuals with valid social security numbers (SSNs). INS supplied a master database for all individuals with valid SSNs who were naturalized between 1900 and 1996 (about 3.2 million) developed for implementing provisions of the Personal Responsibility and Work Opportunity Reconciliation Act of 1996 (PRWORA) and also 1996 and 1997 naturalizations from INS' Central Index System and Redesigned Naturalization Application Casework System. When linked to the SSA Enumeration Verification System, valid SSNs were found for 927,338 records.
} 
at admission because they derive citizenship from parental naturalization, but the derivative citizenship applications may not be filed promptly or the data captured.

The linking strategy relied primarily on matching immigrant records and naturalization records with encrypted alien numbers. More intricate strategies based on the alien number (or Anumber) with sequential ordering and full names that are used by government statisticians, could not be explored because the same information was not released for the project. Alien number was more essential than name, and the percentage of 1977 Cohort records linked with only the alien number that were found mismatched by using name was small (.5 to 1.0) (INS, undated documents). Multi-person linkages (parent-child, husband-wife, sibling-sibling) were not possible without actual, unencrypted alien numbers. Record linkage for immigrants in fiscal year 1982 successfully replicated the INS 1982 Immigrant-Naturalization Cohort (WoodrowLafield, Xu, Kersen \& Poch 1999).

Record linkage procedures were then implemented with all 1978-1981 and 1983-1991 entry cohorts. The discovery was made that both immigrant and naturalization records were duplicated across years and within year as previously found for the Immigrant-Naturalization Cohorts for 1977 (2,960 duplicate cases) and 1982 (12 cases). From 9,085,945 immigrant records over 1978-1992, 8,926,246 records, or 98.2 percent, were accepted as "original" records. This figure resulted from excluding immigrant records without an alien number (279), identifying 8,786,634 records for which the alien number was found only once, identifying 299,032 records for which the alien number was found on multiple records, designating 159,420 records as duplicate records, and excluding the latter. The overcount rate of actual immigrants in publicly released data is thus about 1.8 percent $(100 *((159420+279) /(8786634$ $+299032-159420))$ ). The number of duplicated identification numbers was only 139,612, as some numbers were found among several "duplicate" records.

Among 5,539,763 naturalization records over 1978-1996, 5,475,988, or 98.8 percent, were accepted as "original" records. In creating the naturalization microdata file to merge with the immigrant microdata file, the steps involved excluding records with missing alien number (788), identifying 5,414,074 records for which the alien number was found only once, identifying 124,901 records for which the alien number was found on multiple records, designating 62,987 records as duplicate records,${ }^{2}$ and excluding the latter. Published naturalizations are in error by an overcount rate of about 1.2 percent $(100 *((62987+788) /$ (5414074+124901-62987))). The number of duplicated numbers was only 61,914 as the rest were third or higher-order incidences.

Some duplicates appear as an incomplete record and a complete record, but other duplications seemed to reflect re-assignment of the same number or data entry error. Without actual names, individual case review was not feasible and the best solution was to accept the first case appearing with the alien number as "original" and to designate second or higher order records as "duplicate." 3 In some instances, especially refugee adjustments, the most valid record may be a later one rather than earlier ones, whether the second or a higher order one. ${ }^{4}$ For these cases, another procedure may have been compensatory, in that year of admission as permanent resident from the naturalization record was substituted when the immigrant record showed an

\footnotetext{
${ }_{3}^{2}$ More than one-half were with fiscal year of 1982, and many of the others appeared in the late 1980s and 1994-1996.

3 This solution was based on personal communication with Michael D. Hoefer, who was then Director of the INS Statistics Office, now the Office of Immigration Statistics.

${ }^{4}$ For some refugees admitted before 1982, the first immigrant record may show the date of refugee arrival or the "roll-back" date as date of lawful admission, and the second record may show the accurate date of becoming a lawful permanent resident. In such cases, using the first record would overstate the duration to naturalization relative to those cases for which date was correct. The role of nonimmigrant experience would be understated. In statistical analyses, this error could imply a pattern of earlier cohorts as showing lower pace in naturalizing, especially for shorter durations.
} 
invalid year of admission. One-quarter (25.4 percent) of duplicate immigrant records were for admissions from Vietnam, and another one-quarter were for admissions from the five countries of Laos ( 8.9 percent), Cambodia (5.8 percent), Cuba (5.3 percent), Mexico (4.5 percent) and the Soviet Union (4.2 percent). Immigrants born in seven countries accounted for about onehalf of naturalization duplicates-the Philippines (9.6 percent), Korea (7.2 percent), Mexico (6.8 percent), Cuba (6.8 percent), Vietnam (6.7 percent), China ( 4.9 percent), and India (4.2 percent).

To explore the possibility of selection bias from excluding these duplicate cases (Berk 1990), duplicate status was analyzed as the dependent variable in logistic regressions on characteristics of, first, immigrant records and, second, naturalization records with independent covariates for age group, sex, year, whether country of birth was known, and whether immigrant visa class was under numeric limitation (Table 1). The numerically exempt visa category primarily involved refugees and immediate relatives of citizens, and the countries represented would particularly be the refugee-sending countries of birth in Southeast Asia (Vietnam, Laos, and Cambodia), as well as Cuba, Mexico, and the former Soviet Union.

The probability of duplicate status was greater for immigrant records for categories of numerically exempt visa, unknown country of birth, fiscal year 1979 and unknown sex. Younger immigrants were more likely to have multiple records, perhaps because their first name and surname were reversed when the immigrant record was created with their parents and any siblings, and another immigrant record was generated when processing naturalization applications or for other reasons. Based on the logistic regression analysis of duplicate status within naturalization records, naturalization records in 1981, 1982, 1985, and 1987 were most likely to have a duplicated record. Records with younger and older ages or with unknown sex were likely to be duplicated.

The duplication problem is very likely to stem from statistical processing as, pursuant to the Act of October 28, 1977, refugees became eligible for adjustment to lawful permanent residence under the preference system. When the Refugee Resettlement Act of 1980 specified refugee adjustments as allowed after one year of residence without limitation, many refugees became simultaneously eligible to adjust status and to naturalize. For a substantial number arriving as refugees, the immigrant record was generated at the same time as the naturalization record, and month and year recorded as admission were the arrival date. Even if an initial immigrant record may have been previously generated from the Central Index System (CIS), another immigrant record was subsequently generated upon the refugee's naturalization. These results suggest these procedures are appropriate. These steps are not a formal test of selectivity bias, and we do not speculate on the nature of possible selection bias, but the relative number of duplicates is small. The presence of duplicates in the public use microdata probably has some minor implications although several economic studies of immigrant skills and labor force performance omit refugees, e.g., as in Greenwood and McDowell (1999), Jasso, Rosenzweig, and Smith (1998), and Clark, Hatton, and Williamson (2002).

Restricting analyses to pre-1992 cohorts before the preference system was altered under the Immigration Act of 1990, the INP dataset included 2,805,599 immigrant records ( 31.5 percent) matched with a naturalization record and 6,120,647 immigrant records ( 68.5 percent) remained as not yet corresponding with a naturalization record. Some may have left the United States but emigration is not easily assessed empirically (Woodrow-Lafield 1996; Jasso \& Rosenzweig 1982). Immigration-to-naturalization analytic record refers inclusively to immigrant records linked with a naturalization record and immigrant records censored on naturalization. The current focus is ten origin groups, China, India, Korea, the Philippines, Vietnam, Jamaica, Mexico, Cuba, the Dominican Republic, and Colombia, accounting for 4,682,025 immigrationto-naturalization records or 52.5 percent. This limited examination is acceptable with Mexico 
as the reference category. The entry cohorts of 1978-1987 are selected to allow at least 10 years of lawful residence and as many as 19 years for earlier cohorts. The analyses are restricted to persons aged 21 years and older at immigration because children's citizenship status is contingent on parental naturalization until adulthood. With these restrictions, 1,938,744 immigration-to-naturalization records are analyzed.

The dependent variable is waiting time or duration to naturalization, based on whether an immigrant naturalized by 1996 . For those not naturalizing, the data are right-censored. The duration to naturalization is calculated on the basis of month and year of naturalization and month and year of admission as lawful permanent resident from the immigrant record (substituting the admission year from the naturalization record when missing on the immigrant record). ${ }^{5}$ This variable has two versions: years and "century months" of residence. A small number of cases (375) were deleted because values for duration to naturalization were negative or implausible.

Key covariates are origin country, age group, sex, 6 married at admission, visa class, nonimmigrant adjustment, and fiscal year of admission. The immigrant record captures nonimmigrant experience for those persons making a status adjustment. The data include occupational information at immigrant admission that is regarded as less accurate than occupational data at naturalization because individuals may answer based on either their prior occupation in origin country or that occupation for which an employer has sponsored the individual's visa (Greenwood, Trabka \& McDowell 1991;Greenwood \& McDowell 1999). For non-employment sponsored immigrants, occupation at immigrant admission may not correspond with the occupation in the U.S. labor market. The focus here is class of admission rather than occupation with which admission criteria are correlated.

Most of the covariates are easily categorized as dummy variables. In using country-of-origin dummy variables, this study begins with the simplest case with the caveat that the influential features of the migration context are obscured, but this may not be as severe a problem as with an earnings dependent variable. (See Jasso (1997) for related discussion.) Visa-class of admission includes numerically limited visas distributed among categories of family sponsorship and employment sponsorship and exempt or numerically unlimited visas for immediate relatives, and humanitarian criteria. The distinction according to principals or derivative beneficiaries is incorporated, and the preference categories prior to the Immigration Act of 1990 are designated, for a total of fourteen categories. Among family preferences, first, second, fourth and fifth preferences are translated to seven dummy variables. Third and sixth preferences are translated to four categories. There are two immediate relatives categories: spouses as principals and parents as principals. The last category encompasses refugees, asylees, and others without distinction as to principal or derivative beneficiaries.

This study uses continuous time event-history techniques (Cox \& Oakes 1984) to model the timing and occurrence of naturalization, that is, to study the process of naturalizing over time rather than merely altered citizenship status at time points. The immigration-to-naturalization process is a single-state non-repeatable event process, making this choice relatively simple. Modeling duration to naturalization is advantageous in incorporating fixed characteristics at time of migration and the passage of time itself (Allison 1995; Cox 1972; Cox \& Oakes 1984; Tuma \& Hannan 1984). Estimating determinants of the cumulative probability of having naturalized as of ten years (Jasso \& Rosenzweig 1986) or within broad duration intervals (Rytina 1998) would be a more restricted analysis. Preliminary analyses confirmed

\footnotetext{
${ }_{6}^{5}$ For refugees, the effective date is often arrival date rather than adjustment date.

${ }^{6}$ This item is subject to missing data problems for 1981-1983.
} 
proportionality assumptions of the hazards of naturalization for country-of-birth populations as necessary for application of hazards modeling techniques.

Following Allison (1995), the Cox regression model can be specified and denoted as $\log \mathrm{h}_{\mathrm{i}}(\mathrm{t})=\alpha(\mathrm{t})+\beta_{1} \mathrm{x}_{\mathrm{i} 1}+\ldots+\beta_{\mathrm{k}} \mathrm{X}_{\mathrm{ik}}$

where $\log \mathrm{h}_{\mathrm{i}}(\mathrm{t})$ is the logged hazard rate or transition rate of naturalization and $\alpha(\mathrm{t})=\log \lambda_{0}(\mathrm{t})$ is the baseline hazard function when the covariates are held at 0 . Like ordinary least squares regression models, $\beta$ s are the regression coefficients to be estimated. If $\mathrm{e}^{\beta}$ (the exponential function) is performed, the regression coefficients can be intuitively interpreted as the hazards or hazard ratios (Allison 1995). Unless specified, the partial likelihood estimation method in SAS was used to estimate Cox proportional hazard regression models. Ties when naturalization occurred in the same month for multiple immigrants are handled with the exact method in SAS.

\section{RESULTS}

\section{Descriptive Results}

The distribution on class of admission (Table 2) reflects well-known concentrations on family criteria and humanitarian criteria with lesser percentages for employment- sponsored categories. At immigration, most adult immigrants ( 73 percent) were married, ranging from 58 percent for Vietnamese immigrants to 87 percent for Mexico, and most were in their 20s, 30 s, or 40s. The distribution on fiscal year cohort generally reflects changes in immigration law, source country conditions, and refugee admissions, as well as changes in immediate relatives admissions. As historically evident (Donato 1992; Houston et al. 1984), more than one-half were women (52 percent), and there was a female majority for several origin countries (China, 54 percent; Korea, 61 percent; the Philippines, 63 percent; Jamaica, 54 percent; the Dominican Republic, 52 percent; and Colombia, 57 percent).

Slightly more than one-quarter (27.7 percent) adjusted from temporary resident or nonimmigrant status, including refugee status. For refugee-sending countries, the proportion having U.S. experience is very high-76 percent for Vietnamese immigrants and 77 percent for Cuban immigrants. For non-refugee sending countries, the proportion having such prior experience was much lower, one in five or six, although these results understate the number of immigrants actually having prior experience.

Pooling across countries, 42 percent had naturalized as of the end of fiscal year 1996 (Table 3 ), curiously commensurate with the percent naturalized for both the adult foreign-born population in the 1990 census (Chiswick \& Sullivan 1995) and the foreign-born population in the 2000 census, and higher than for the 1971 cohort's first decade (37 percent of those 21-65 years at admission) (Jasso \& Rosenzweig 1990). The census proportion may be overstated by response errors (Passel \& Clark 1997; Passel, Clark \& Fix 1998;Fix \& Passel 1994;Woodrow $1992)$ and by exclusion of emigrants. The highest percentages are for Vietnam (65 percent), the Philippines (62 percent) and China (51 percent). The percentage naturalized for Colombia (46 percent), Cuba (40 percent), and Jamaica (37 percent) are quite comparable to two other Asian countries-India (44 percent) and Korea (38 percent). The lowest percentages are for Mexico (18 percent) and the Dominican Republic (24 percent). The percentage naturalized is higher for earlier entry cohorts having had more time to naturalize. Immigrants from China, Cuba, India, and Korea may be less willing to take on U.S. citizenship because they would have to give up their original citizenship, although this seems less relevant to the Chinese case. The medians on duration to naturalization (not shown) showed variation similar to median durations for naturalizations annually, with Asians having shorter intervals as permanent residents before naturalizing than North Americans.

Popul Res Policy Rev. Author manuscript; available in PMC 2009 January 2. 
Employment-sponsored immigrants showed higher naturalization than family-sponsored immigrants, and those admitted under professional categories showed higher naturalization. Women have somewhat higher naturalization levels, as are also found for younger and married immigrants with the exception of married immigrants from Vietnam. Those immigrants with nonimmigrant experience, i.e., adjustments, were more likely to be naturalized. Patterns on age group, marital status, nonimmigrant experience appeared similar for specific countries, but men from China, India, and Vietnam showed higher percentages naturalized than women, whereas women from these Latin American countries showed higher percentages naturalized than men.

\section{Results from Hazards Modeling}

The multivariate Cox regression model $^{7}$ for the duration to naturalization for this pooled dataset of immigrants (Table 4) permits examination of differentials in the occurrence and timing of naturalization by origin, mode of entry, and visa class of admission, net of the effects of demographic and background characteristics. Hazard ratios are also shown here.

All individual country effects were significant, showing greater propensity to naturalize relative to Mexicans, especially for these Asian immigrants, especially those from the Philippines (2.04), Vietnam (1.80), and China (1.78), followed by those from Cuba (1.28), India (1.28), Korea (1.14), and Colombia (1.12). Immigrants from the Philippines, Vietnam, and China are six to eight times as likely to naturalize as Mexican immigrants. Those from countries for which the political contexts may be a disincentive to return, Cuba and Korea, are more likely to naturalize. Recalling observed differentials with INP data and the 1977 and 1982 cohorts (INS 1999), an interesting result is the relative propensities to naturalize for immigrants from the Philippines and Vietnam when other covariates are included. Adjusting immigrants with prior U.S. experience (.25) have greater naturalization propensity.

Among categories for class of admission, all covariates were significant. As hypothesized, admission under spousal categories (that is, spouses of citizens (.27), spouses of permanent residents (.23), spouses of married sons or daughters of citizens (.01), and spouses of siblings of citizens (.12)) was associated with greater propensity to naturalize relative to the reference group of refugees and asylees. Employment-sponsored immigrants, professional (.35) and skilled (.37), also had greater propensity to do so. Parents of citizens (-.27), married sons or daughters of citizens (-.11), unmarried sons or daughters of citizens (-.03), siblings of citizens (-.06), and children of aliens (-.08) were less likely to naturalize. These individuals are joining their nuclear families and may not need to naturalize to help others toward that goal.

Age at immigration and entry year cohort also appear significant in the timing of naturalization. As in other studies, immigrants younger at admission are more likely to naturalize than older individuals, and the relationship is distinct compared with 1987 admissions. Admission in more recent dates appeared associated with greater propensity to naturalize, meaning recent cohorts were progressing to naturalization on a quicker trajectory than had earlier cohorts, net other covariates. Sex was not a significant covariate in the timing of naturalization in this pooled analysis. The male advantage in naturalizing that was apparent in observed rates for China, India, and Vietnam may have stemmed from the visa class composition or underlying occupational structure.

\footnotetext{
${ }^{7}$ In feasibility testing, we initially calculated models with SPSS Version 10, and subsequently used the SAS package for its better capability to handle tied cases (Allison 1995). The EFRON method proved more feasible than the EXACT method due to the latter's extended processing times with the full file.
} 


\section{CONCLUSION AND DISCUSSION}

This examination of the timing of naturalizing for immigrants from ten major sending countries with at least a decade of residence in America demonstrates the effects of origin, immigrant visa class, and mode of entering as a newly arriving immigrant or as a nonimmigrant. Although composition of origin-specific immigration varies on immigrant visa class, origin differences are consistent with observed patterns of higher naturalization for Filipinos, Vietnamese, and Chinese immigrants than for Indians and Koreans, or for Cubans, Colombians, Dominicans, Jamaicans, or Mexicans. A central premise of immigration policy, that immigrants should be able to unify their families on these shores, apparently influences the process of naturalizing. Both employment-sponsored immigrants and certain family-sponsored immigrants, who are likely to have fewer rather than more relatives here, are likely to naturalize quickly, perhaps to gain sponsorship privileges. Having been a nonimmigrant before becoming an immigrant is an important contributor to becoming naturalized, net the effect of arriving as a refugee. This additional time for learning English and about opportunities for residence, employment, and education is valuable for some individuals in, first, making the transition to permanent resident status and, second, making the transition to naturalized citizenship.

The New Chosen People volume (Jasso \& Rosenzweig 1990) made seminal contributions to understanding U.S. immigration and admission policies. With these multiple cohorts, the highly heterogeneous patterns of immigrants' transitions into American citizenship may be illuminated as to the influences of mode of entry and admission criteria within origin and gender. More investigation of gender as a covariate of naturalizing is warranted because gender composition of immigrants is likely to be highly structured on origin and visa class of admission (Bagchi 2001; Dauvergne 2000; Donato 1992). The lack of current socioeconomic characteristics in the INP dataset may prove a less serious shortcoming given data strengths for examining the process of naturalizing. Many key studies similarly lack current characteristics information (Rogers, Hummer \& Nam 1999). Cross-sectional surveys have ample evidence of current or post-immigration characteristics, including socioeconomic measures and citizenship, but these lack date of naturalization. In the course of one to two decades, the New Immigrant Survey (Jasso, Rosenzweig, Massey \& Smith 1997a, b, 2000a, b), with admission and post-immigration characteristics, may be an ideal resource for naturalization analyses. Future analyses of this longitudinal data may assess the consequences of welfare reform, immigrants' fears as to loss of rights and possible deportation, and shifts in provisions for dual nationality for immigrant naturalization in the late 1990s and beyond.

The balancing of family-sponsored and employment-sponsored criteria is the crux of contemporary controversies of immigrant integration and immigration policy. The basic structure of immigration admission policies has been substantially unchanged over 1970-2000, but proposals to drastically reduce levels or to greatly restrict family-based categories arise intermittently. One argument (Borjas 1999) is that immigrant skill levels relative to native skill levels have been declining since the 1980s, and that immigrant admission policies should be altered to emphasize employment qualifications more and to curtail family unification. An alternative argument (Jasso, Rosenzweig \& Smith 1998) demonstrated skill levels of new immigrants as rising relative to natives, at least since the mid 1980s. The debate revolves on spokes of data type and origin-specificity.

Addressing policy questions about admission of different types of immigrants with consideration of their ultimate outcomes as members of American society will best be pursued through augmenting the present data with both new immigrant entry cohorts and additional naturalizations records for post-1996. Naturalizations in 1994-2001 were at historically high numbers $(1,044,689$ naturalizations in 1996, 598,225 in 1997, 463,060 in 1998, 839,944 in $1999,888,788$ in 2000, 608,205 in 2001, and 573,708 in 2002) (DHS 2003). In 1991-2000, 
there were more than five million naturalization approvals from seven million applications (INS 2000). Administrative delays in processing applications for naturalization delayed many immigrants' transition to naturalized status over 1995-2000.

Although these findings point to the lesser likelihood of naturalizing among Mexican immigrants, a new era may be beginning in Mexicans' becoming U.S. citizens. As Mexican immigrants increased in the late 1980s and 1990s, Mexico became the leading country of origin for persons naturalizing in 1994-2000. Many Mexicans naturalizing recently had legalized under IRCA and been resident for more than a decade as unauthorized aliens after reaching eligibility to apply as of September 1995. More than one-half of Mexicans naturalizing in 1996-2000 had received amnesty. The total number of IRCA legalized aliens naturalized by the end of 2000 was about 815,669 (30 percent), including 152,319 from Mexico (INS 2002). The research question of whether propensities to naturalize may be changing among Mexican immigrants is only one of many questions that can be addressed through this research undertaking in the future.

\section{Acknowledgements}

An earlier version was presented at the 2000 Joint Statistical Meetings, American Statistical Association, in Indianapolis. This research was supported by a grant to the first author from the National Institute of Child Health and Human Development (NICHD) (R01 HD37279) and the cooperation of the Statistics Office in the former U.S. Immigration and Naturalization Service, now the Office of Immigration Statistics in the Department of Homeland Security, is acknowledged in making this work possible. We thank Felicia LeClere whose comments were most valuable for this version. The contents are solely the responsibility of the authors and do not necessarily represent the official views of the NICHD or the National Institutes of Health.

\section{REFERENCES}

Allison, PD. Survival analysis using the SAS system: A practical guide. SAS Institute; Cary, N.C.: 1995.

Aguirre BE, Saenz R. Testing the effects of collectively expected durations of migration: The naturalization of Mexicans and Cubans. International Migration Review 2002;36:103-124.

Astone N, Nathanson C, Schoen R, Kim YJ. Family demography, social theory, and investment in social capital. Population and Development Review 1999;25:1-31.

Bagchi AD. Migrant networks and the immigrant professional: An analysis of the role of weak ties. Population Research and Policy Review 2001:9-31.

Bean, FD.; Hook, JV.; Woodrow-Lafield, KA. Estimates of numbers of unauthorized migrants residing in the United States: The total, Mexican, and non-Mexican Central American unauthorized populations in mid-2001, Special Report, November 2001. Pew Hispanic Center; 2001. www.pewhispanic.org

Bean FD, Corona R, Tuirán R, Woodrow-Lafield KA, Hook JV. Circular, invisible, and ambiguous migrants: Components of difference in estimates of the number of unauthorized Mexican migrants in the United States. Demography 2001;38(3):411-422. [PubMed: 11523268]

Bean, FD.; Corona, R.; Tuirán, R.; Woodrow-Lafield, KA.; Binational Migration Study. Migration between Mexico and the United States: Binational Study, Volume I, Thematic Chapters. U.S. Commission on Immigration Reform and Mexican Ministry of Foreign Affairs; 1998. The quantification of migration between Mexico and the United States, “; p. 1-90.http://www.utexas.edu/lbj/uscir/binpapers/v1-1bean.pdf

Bean, FD.; Chapa, J.; Berg, RR.; Sowards, KA. Educational and sociodemographic incorporation among Hispanic immigrants to the United States. In: Edmonston, B.; Passel, JS., editors. Immigration and ethnicity: The integration of America's newest arrivals. The Urban Institute Press; Washington, D.C.: 1994. p. 73-100.

Berk RA. An introduction to sample selection bias in sociological data. American Sociological Review 1983;4:386-398.

Binational Migration Study. Migration between Mexico and the United States: Binational Study. U.S. Commission on Immigration Reform and Mexican Ministry of Foreign Affairs; 1997. 
Blossfeld, H.; Hamerle, A.; Mayer, KU. Event history analysis: Statistical theory and application in the social sciences. Lawrence Erlbaum Associates, Publishers; Hillsdale, NJ: 1989.

Borjas, G. Heaven's door: Immigration policy and the American economy. Princeton University Press; Princeton: 1999.

Bustamante, J.; Jasso, G.; Taylor, JE.; Trigueros Legarreta, P.; Binational Migration Study. Migration between Mexico and the United States: Binational Study, Volume I, Thematic Chapters. U.S. Commission on Immigration Reform and Mexican Ministry of Foreign Affairs; 1998. Characteristics of migrants: Mexicans in the United States; $p$. 91-162.http://www.utexas.edu/lbj/uscir/binpapers/v1-2bust.pdf

Chiswick, BR.; Sullivan, TA. The new immigrants. In: Farley, R., editor. State of the Union: America in the 1990s, Volume Two: Social Trends. Russell Sage Foundation; New York: 1995. p. 211-270.

Clark, X.; Hatton, TJ.; Williamson, JG. Where do U.S. immigrants come from, and why?. National Bureau of Economic Research; presented at the 2002 annual meeting of the Population Association of America; Atlanta. 2002; NBER Working Paper No. 8998

Cox DR. Regression models and life tables. Journal of the Royal Statistical Society 1972;B34:187-220.

Cox, DR.; Oakes, D. Analysis of survival data. Oxford; London: 1984.

Crimmins EM. Demography: The past 30 years, the present, and the future. Demography 1993;30:579592. [PubMed: 8262281]

Dauvergne C. Citizenship, migration laws and women: Gendering permanent residency statistics.“. Melbourne University Law Review 2000;24:18.

De Jong G, Legazpi Blair MC. Changing occupational characteristics of U.S. immigrants. Asian and Pacific Migration Journal 1994;3:567-588. [PubMed: 12346390]

DeSipio L. Social science literature and the naturalization process. International Migration Review 1987;21:390-405.

DeSipio, L.; de la Garza, RO. Making Americans, remaking America: Immigration \& immigrant policy. Westview Press; 1998.

Donato, KM. Understanding U.S. immigration: Why some countries send women and others send men. In: Gabaccia, D., editor. Seeking common ground: Multidisciplinary studies of immigrant women in the United States. Greenwood Press; Westport, CT: 1992. p. 141-148.

Espenshade, T., editor. A stone's throw from Ellis Island. University Press of America; 1994.

Fix, M.; Passel, JS. Immigration and immigrants: Setting the record straight. The Urban Institute; Washington, D.C.: 1994.

Gibson, C.; Lennon, E. Historical census statistics on the foreign-born population of the United States: 1850 to 1990. Population Division, U.S. Census Bureau; 1999. Working Paper No. 29

Greenwood, MJ.; McDowell, JM. Legal U.S. immigration: Influences on gender, age, and skill composition. W.E. Upjohn Institute for Employment Research; Kalamazoo, MI: 1999.

Greenwood MJ, Waldman DM, Zahniser SS. The influence of social programs in source countries on various classes of U.S. immigration. Journal of the American Statistical Association 1999;94:64-75. [PubMed: 12155404]

Greenwood MJ, Waldman DM. A model of the skill composition of U.S. immigration. Applied Economics 1996;28:299-308.

Greenwood, MJ.; Ziel, FA. The impact of the Immigration Act of 1990 on U.S. immigration. 1997.

Greenwood MJ, McDowell JM, Trabka E. Conducting descriptive and analytic research with the Immigration and Naturalization Service public-use tapes. Journal of Economic and Social Measurement 1991;17:131-154.

Hirschman, C.; Kasinitz, P.; De Wind, J., editors. The handbook of international migration: The American experience. Russell Sage; New York: 1999.

Houstoun MF, Kramer RG, Barrett JM. Female predominance in immigration to the United States since 1930: A first look. International Migration Review 1984;18:908-963. [PubMed: 12340340]

Jasso, G. Migration and the dyamics of family phenomena. In: Booth, A.; Crouter, AC.; Landale, N., editors. Immigration and the family: research and policy on U.S. immigrants. Lawrence Erlbaum \& Associates; Mahwah: 1997. p. 63-78. 
Jasso G, Rosenzweig MR. Estimating the emigration rates of legal immigrants using administrative and survey data: The 1971 cohort of immigrants to the United States. Demography 1982;19:279-290. [PubMed: 7117627]

Jasso G, Rosenzweig MR. Family reunification and the immigration multiplier: U.S. immigration law, origin-country conditions, and the reproduction of immigrants. Demography 1986;23:291-312. [PubMed: 3758442]

Jasso, G.; Rosenzweig, MR. How well do U.S. immigrants do? Vintage effects, emigration selectivity, and occupational mobility. In: Schultz, TP., editor. Research in Population Economics. 6. 1988. p. 229-253.

Jasso, G.; Rosenzweig, M. The new chosen people: Immigrants in the United States. Russell Sage Foundation; New York: 1990.

Jasso G, Rosenzweig M. Do immigrants screened for skills do better than family reunification immigrants? International Migration Review 1995;29:85-117. [PubMed: 12319616]

Jasso, G.; Rosenzweig, MR.; Smith, JP. The changing skill of new immigrants to the United States: Recent trends and their determinants. National Bureau of Economic Research; Cambridge, Massachusetts: 1998. Working Paper 6764http://www.nber.org/papers/W6764

Jasso, G.; Massey, DS.; Rosenzweig, MR.; Smith, JP. The New Immigrant Survey (NIS) Pilot Study: Preliminary results; Revised version of paper presented at the 1997 Joint Meeting of the Public Health Conference on Records and Statistics and the Data Users Conference; Washington, D.C.. 1997b; Jul.

Jasso G, Massey DS, Rosenzweig MR, Smith JP. The New Immigrant Survey Pilot (NIS-P): Overview and new findings about U.S. legal immigrants at admission. Demography 2000a;37:127-138. [PubMed: 10748994]

Jasso G, Massey DS, Rosenzweig MR, Smith JP. Assortative mating among married legal immigrants to the United States: Evidence from the New Immigrant Pilot Survey. International Migration Review 2000b;34:443-460.

Jones-Correa M. Under two flags: Dual nationality in Latin America and its consequences for the United States. International Migration Review 2001;35:997-1029.

Jones-Correa M. Different paths: Gender, immigration, and political participation. International Migration Review 1998;32:0326-0349.

Kanjanapan W. The immigration of Asian professionals to the United States: 1988-1990. International Migration Review 1995;29:7-32. [PubMed: 12319615]

Kraly EP, Warren R. Long-term immigration to the United States: New approaches to measurement. International Migration Review 1991;25:60-92. [PubMed: 12316778]

Kraly EP, Warren R. Estimates of long-term immigration to the United States: Moving U.S. statistics toward United Nations concepts. Demography 1992;29:613-626. [PubMed: 1483545]

Levine, DB.; Hill, K.; Warren, R. Immigration statistics: A story of neglect. National Academy Press; Washington, D.C.: 1985.

Liang Z. On the measurement of naturalization. Demography 1994;31:525-548. [PubMed: 7828770]

Liu J, Ong PM, Rosenstein C. Dual chain migration: Post-1965 Filipino immigration to the United States. International Migration Review 1991;25:487-513. [PubMed: 12284363]

Lindstrom DP, Massey DS. Selective emigration, cohort quality, and models of immigrant assimilation. Social Science Research 1994;23:315-349.

Lobo AP, Salvo JJ. Changing U.S. immigration law and the occupational selectivity of Asian immigrants. International Migration Review 1998;32:0737-0760.

Lobo AP, Salvo JJ. Resurgent Irish immigration to the US in the 1980s and early 1990s: A Sociodemographic profile. International Migration 2000;36:257-280. [PubMed: 12293798]

Massey DS. The new immigration and ethnicity in the United States. Population and Development Review 1995;21:631-652.

Massey DS, Malone N. Pathways to legal immigration. Population Research and Policy Review 2002;21:473-504.

Massey, D.; Alarcon, R.; Durand, J.; Gonzalez, H. Return to Aztlan: The social process of international migration from Western Mexico. University of California Press; Berkeley: 1987. 
Massey, DS.; Arango, J.; Hugo, G.; Kouaouci, A.; Pellegrino, A.; Taylor, JE. Worlds in motion: Understanding international migration at the end of the millenium. Oxford University Press; New York: 1998.

Nee, V.; Alba, R. Rethinking assimilation theory for a new era of immigration. In: Hirschman, C.; Kasinitz, P.; DeWind, J., editors. The handbook of international migration: The American experience. Russell Sage Foundation; New York: 1999. p. 137-160.

Passel, JS.; Clark, R. How many naturalized citizens are there? An assessment of data quality in the decennial census and CPS; Presented at the annual meeting of the Population Association of America; Washington, D.C.. 1997;

Passel, JS.; Clark, RL.; Fix, M. Naturalization and other current issues in U.S. immigration: Intersections of data and policy; Proceedings of the Social/Government Statistics Section, American Statistical Association, 1997 Joint Statistical Meetings; 1998; p. 1-10.

Renshon, S. Dual citizens in America: An issue of vast proportions and broad significance. Center for Immigration Studies; Washington, D.C.: 2000.

Renshon, S. Dual citizenship and American national identity: A dilemma of Diversity. Center for Immigration Studies; Washington, D.C.: 2001.

Roberts, BR. Socially Expected Durations and the Economic Adjustment of Immigrants. In: Portes, A., editor. The economic sociology of immigration. Russell Sage Foundation; 1995. p. 42-86.

Rogers, RG.; Hummer, RA.; Nam, CB. Living and dying in the USA. Academic Press; Orlando: 1999.

Rumbaut R. The crucible within: Ethnic identity, self-esteem, and segmented assimilation among children of immigrants. International Migration Review 1995;28:748-794.

Rytina, N. The timing of naturalization in the U.S. through 1996: The experience of the legal immigrant cohorts of 1977 and 1982; Revised presentation at the annual meeting of the Population Association of America; Chicago. March 1998; Washington, D.C: Statistics Office, U.S. Immigration and Naturalization Service; 1998. Working Paper No. 98-01

Salvo, J.; Ortiz, R. The newest New Yorkers: An analysis of immigration into New York City during the 1980s. Jun. 1992 DCP \#92-16

Schmidley, AD. Profile of the foreign-born population in the United States: 2000. U.S. Census Bureau, Current Population Reports, Special Studies. U.S. Government Printing Office; Washington, D.C.: 2001. p. P23-206.

Schmidley, AD.; Gibson, C. Profile of the foreign-born population in the United States: 1997. U.S. Government Printing Office; Washington, D.C.: 1999. U.S. Census Bureau, Current Population Reports, Special Studies, P23-195

Singer, A.; Friedman, S.; Cheung, I.; Price, M. The world in a zip code: Greater Washington, D.C. as a new region of immigration. Center on Urban \& Metropolitan Policy, The Brookings Institution; Washington: Apr. 2001

Smith, JP.; Edmonston, B., editors. The new Americans: Economic, demographic, and fiscal effects of immigration. National Academy Press; Washington, D.C.: 1997. Panel on the Demographic and Economic Impacts of Immigration, Committee on Population and Committee on National Statistics, National Research Council

Spiro, PJ. Carnegie Endowment for International Peace. International Migration Policy Program; Washington, D.C.: 1999. Embracing dual nationality.

Tilly, C. Transplanted Networks. In: Yans-McLaughlin, V., editor. Immigration Reconsidered: History, Sociology, and Politics. Oxford University Press; New York: 1990. p. 79-95.

Tienda M. Demography and the social contract. Demography 2002;39:587-616. [PubMed: 12471845]

Tuma, N.; Hannan, M. Social dynamics: Models and methods. New York: 1984.

Tyree A, Donato KM. The sex composition of legal immigrants to the United States. Sociology and Social Research 1985;69:577-589.

U.S. Bureau of the Census. Historical statistics of the United States, colonial times to 1970. U.S. Government Printing Office; Washington, D.C.: 1975.

U.S. Department of Homeland Security. Yearbook of immigration statistics. Office of Immigration Statistics. U.S. Government Printing Office; Washington, D.C.: 2002. 
U.S. General Accounting Office. Public assistance benefits provided to recently naturalized citizens. Washington, D.C.: Jun. 1999 GAO/HEHS-99-1021999

U.S. General Accounting Office. Record linkage and privacy: Issues in creating new federal research and statistical information. 2001. GAO-01-126SP

U.S. Immigration and Naturalization Service. Adjudications update-Second quarter, FY 2000. INS Backgrounder; May 26. 2000

U.S. Immigration and Naturalization Service. 1996 Statistical Yearbook of the U.S. Immigration and Naturalization Service. U.S. Government Printing Office; Washington, D.C.: 1998.

U.S. Immigration and Naturalization Service. 1997 Statistical Yearbook of the U.S. Immigration and Naturalization Service. U.S. Government Printing Office; Washington, D.C.: 1999.

U.S. Immigration and Naturalization Service. Documentation package for the 1977 immigrantnaturalization cohort. Statistics Division; Washington, D.C.: n.d.

U.S. Immigration and Naturalization Service. Documentation package for the 1982 immigrantnaturalization cohort. Statistics Division; Washington, D.C.: n.d.

Wachter, K. The imputation and treatment of missing data. In: Levine, DB.; Hill, K.; Warren, R., editors. Immigration statistics: A story of neglect. National Academy Press; Washington, D.C.: 1985. p. 251-254.

Weintraub, S.; Mexico-United States Binational Migration Study. Migration between Mexico and the United States: Binational Study, Volume 2, Research reports and background materials. Mexican Ministry of Foreign Affairs and U.S. Commission on Immigration Reform; 1998. On the unrenounceability of Mexican nationality; $\mathrm{p}$. 1249-1250.http://www.utexas.edu/lbj/uscir/binpapers/

Wood C. Losing control of America's future--the Census, birthright citizenship and illegal aliens. Harvard Journal of Law and Public Policy 1999 Spring;22(2):465-522.

Woodrow, KA. Research and Evaluation Memorandum No. 75. U.S. Bureau of the Census; 1991. DA Project D2: Preliminary estimates of undocumented residents in 1990.

Woodrow KA. A consideration of the effect of immigration reform on the number of undocumented residents in the United States. Population Research and Policy Review 1992;11:117-144.

Woodrow, KA.; Passel, JS. Post-IRCA undocumented immigration to the United States: Assessment based on the June 1988 CPS. In: Bean, FD.; Edmonston, B.; Passel, JS., editors. Undocumented migration to the United States: IRCA and the experience of the 1980s. The Urban Institute Press; 1990. Chapter 2

Woodrow-Lafield, KA. Potential sponsorship by IRCA-legalized immigrants. U.S. Commission on Immigration Reform; Washington, D.C.: 1995. http://www.utexas.edu/lbj/uscir/respapers/ps-s94

Woodrow-Lafield, KA. To dream of American citizenship and family unification: The long welcome; Proceedings of the Social/Government Statistics Section, American Statistical Association, 1997 Joint Statistical Meetings; 1998; p. 11-19.

Woodrow-Lafield, KA. Demographic effects of legalization, Working Paper, Bureau of International Labor Affairs, Division of Immigration Policy and Research, U.S. Department of Labor, Based on Final Report. 1996. revised March 1995

Woodrow-Lafield, KA.; Mexico-United States Binational Migration Study. Migration Between Mexico and the United States: Binational Study, Volume 2, Research Reports and Background Materials. Mexican Ministry of Foreign Affairs and U.S. Commission on Immigration Reform; 1998. Estimating authorized immigration; $p$. 619-682.http://www.utexas.edu/lbj/uscir/binpapers/v2a-5woodrow.pdf

Woodrow-Lafield, KA.; Xu, X.; Kersen, T.; Poch, B. Naturalization experiences of U.S. immigrants; Proceedings of the Social/Government Statistics Section, American Statistical Association, 2000 Joint Statistical Meetings; 2001; p. 106-111.

Woodrow-Lafield, KA.; Xu, X.; Kersen, T.; Poch, B. Naturalization for 1982 and 1987 Mexican immigrant cohorts; Revised version of paper presented at the 1999 annual meeting of the Southern Demographic Association; San Antonio. 1999;

Yang PQ. Explaining immigrant naturalization. International Migration Review 1994;28:449-477. [PubMed: 12345790]

Zelinsky W. The hypothesis of the mobility transition. Geographical Review 1971;61:219-249. 
Table 1

Coefficients of Logistic Regression Models For Duplicate Status

\begin{tabular}{|c|c|c|c|c|}
\hline & \multicolumn{2}{|c|}{ Immigrant Records 1978-1992 } & \multicolumn{2}{|c|}{ Naturalization Records 1978-1996 } \\
\hline Covariates $\underline{I}$ & $\underline{B}$ & (S.E.) & B & (S.E.) \\
\hline Numerically exempt visa & 3.755 & $(0.024)^{* * *}$ & $\mathrm{~N} / \mathrm{A}$ & \\
\hline Stateless & 0.728 & $(0.008)^{\text {**** }}$ & $\mathrm{N} / \mathrm{A}$ & \\
\hline Females & -0.114 & $(0.005)^{\text {*** }}$ & -0.022 & $(0.009)^{* * *}$ \\
\hline Unknown Sex & 0.604 & $(0.169)^{* * *}$ & 1.272 & $(0.024)^{\text {*** }}$ \\
\hline Under 18 years & 0.122 & $(0.006)^{* * *}$ & 0.144 & $(0.021)^{*}$ \\
\hline $65+$ years & -0.415 & $(0.014)^{* * *}$ & 0.145 & $(0.019)^{*}$ \\
\hline 1979 & 2.281 & $(0.011)^{\text {**\% }}$ & -0.404 & $(0.045)^{* 2}$ \\
\hline 1980 & -0.598 & $(0.017)^{* * * *}$ & -0.015 & $(0.041)$ \\
\hline 1981 & -2.406 & $(0.033)^{* * * *}$ & 0.372 & $(0.037)^{*}$ \\
\hline 1982 & -0.896 & $(0.026)^{* * *}$ & 3.441 & $(0.029)^{*}$ \\
\hline 1983 & -2.787 & $(0.028)^{* * *}$ & -1.200 & $(0.058)^{*}$ \\
\hline 1984 & -4.505 & $(0.036)^{* * * *}$ & -0.338 & $(0.042)^{*}$ \\
\hline 1985 & -4.713 & $(0.037)^{\text {*** }}$ & 0.140 & $(0.035)^{*}$ \\
\hline 1986 & -4.927 & $(0.038)^{\text {*** }}$ & -0.811 & $(0.043)^{*}$ \\
\hline 1987 & -4.894 & $(0.038)^{* * *}$ & 0.710 & $(0.033)^{*}$ \\
\hline 1988 & -5.003 & $(0.038)^{*}$ & -0.384 & $(0.040)^{3}$ \\
\hline 1989 & -5.947 & $(0.054)^{* * *}$ & -0.491 & $(0.042)^{* * *}$ \\
\hline 1990 & -6.366 & $(0.062)^{\text {*** }}$ & 0.039 & $(0.035)$ \\
\hline 1991 & -6.439 & $(0.060)^{* * * *}$ & -1.365 & $(0.049)^{* * * *}$ \\
\hline 1992 & -6.945 & $(0.068)^{* * *}$ & -1.257 & $(0.052)^{*}$ \\
\hline 1993 & $\mathrm{~N} / \mathrm{A}$ & & -0.961 & $(0.044)^{*}$ \\
\hline 1994 & $\mathrm{~N} / \mathrm{A}$ & & 0.359 & $(0.032) *$ \\
\hline 1995 & $\mathrm{~N} / \mathrm{A}$ & & -0.516 & $(0.035)^{*}$ \\
\hline 1996 & N/A & & -0.939 & $(0.033)^{* * *}$ \\
\hline Constant & 4.370 & $(0.011)$ & -4.907 & $(0.029)$ \\
\hline$-2 \log$ likelihood & & $1,070,581.5$ & & $530,082.2$ \\
\hline$X^{2}$ & & $536,597.1$ & & $159,112.6$ \\
\hline $\mathrm{DF}$ & & 20 & & 22 \\
\hline $\mathrm{N}$ & & $9,085,945$ & & $5,538,975$ \\
\hline
\end{tabular}

For naturalization records, the covariates reflect immigrant characteristics when naturalized.

${ }^{1}$ For immigrant records, the covariates reflect immigrant characteristics at admission.

***

$\mathrm{p}<.001$

**

$\mathrm{p}<.01$ 


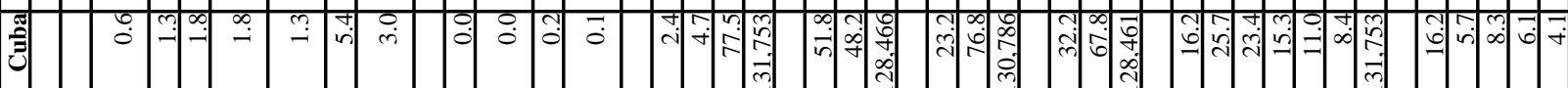

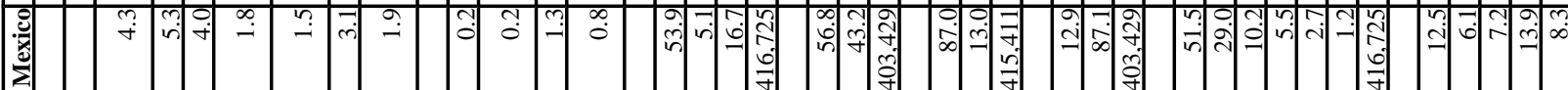

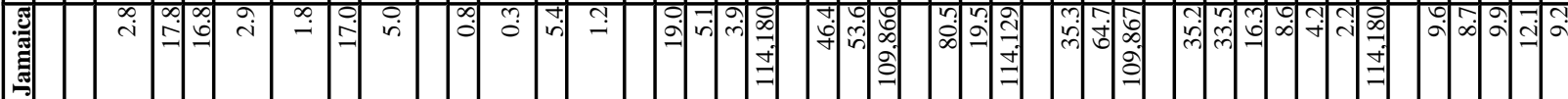

$\Xi$

弹

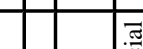




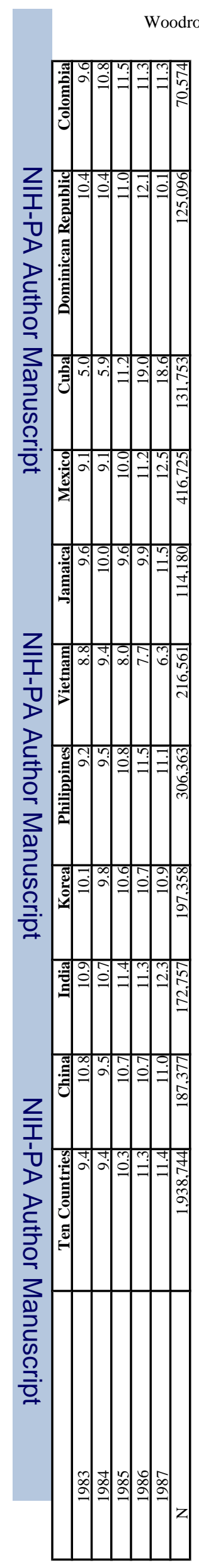

Page 21

Popul Res Policy Rev. Author manuscript; available in PMC 2009 January 2. 


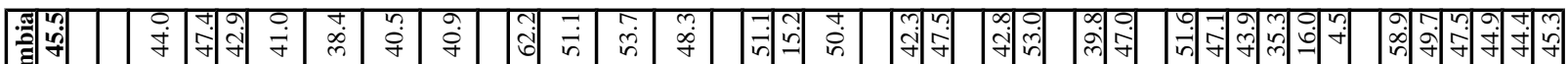
의

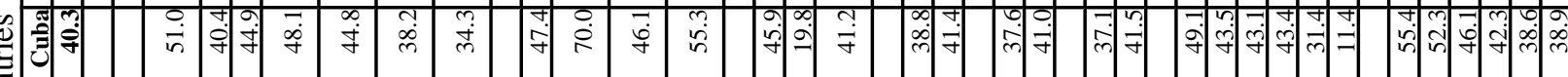

绨 (2)

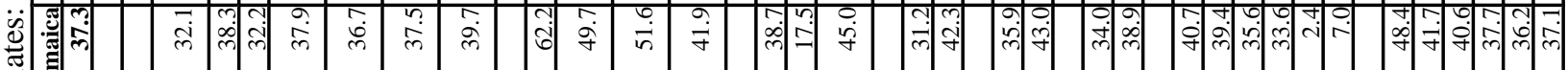

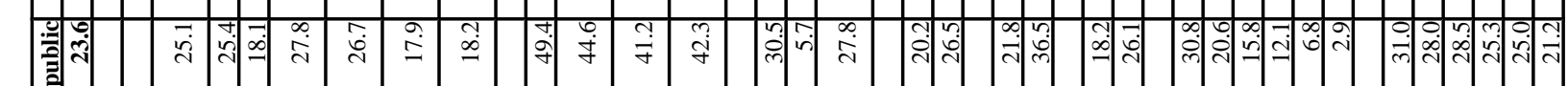
:

音

$\overbrace{}^{3}$

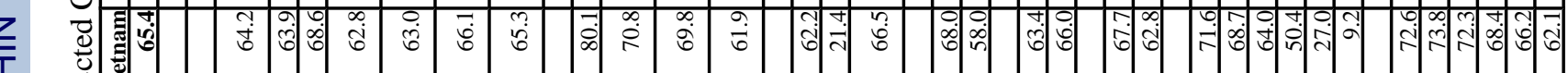

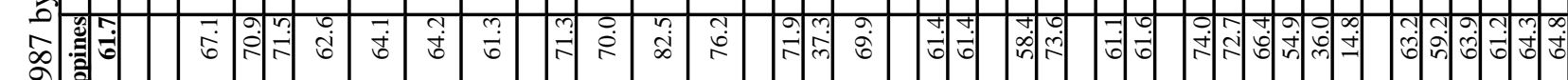
$\stackrel{\infty}{\stackrel{0}{*}}$

$\frac{0}{0}$

वृ

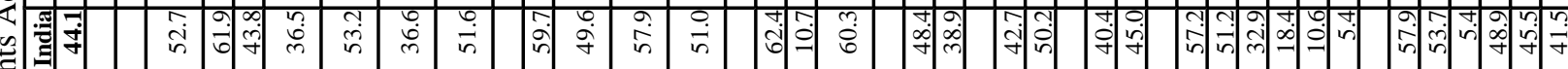

西

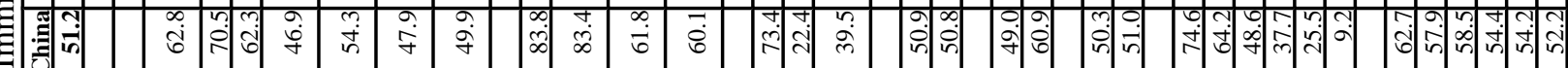

ᄒ

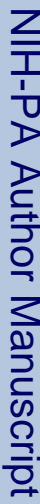

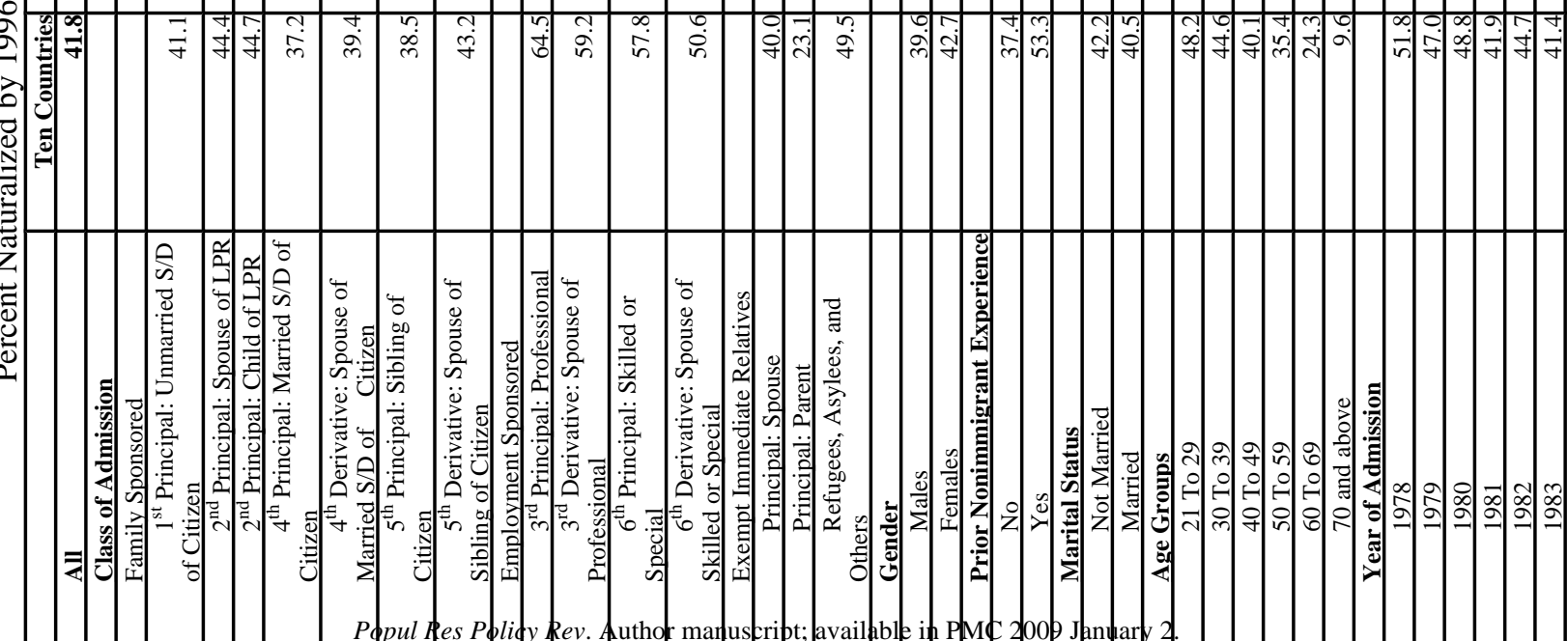




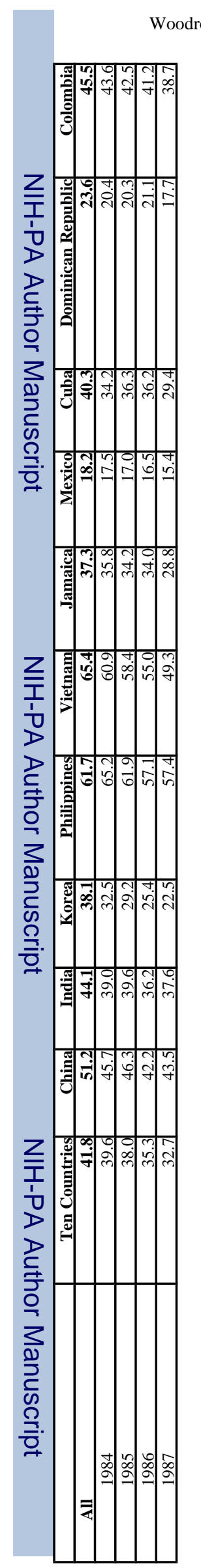

Page 23

oodrow-Lafield et al. 
Table 4

Maximum Likelihood Estimates of Multivariate Cox Regression Model for Naturalization: Immigrants Admitted in 1978-1987

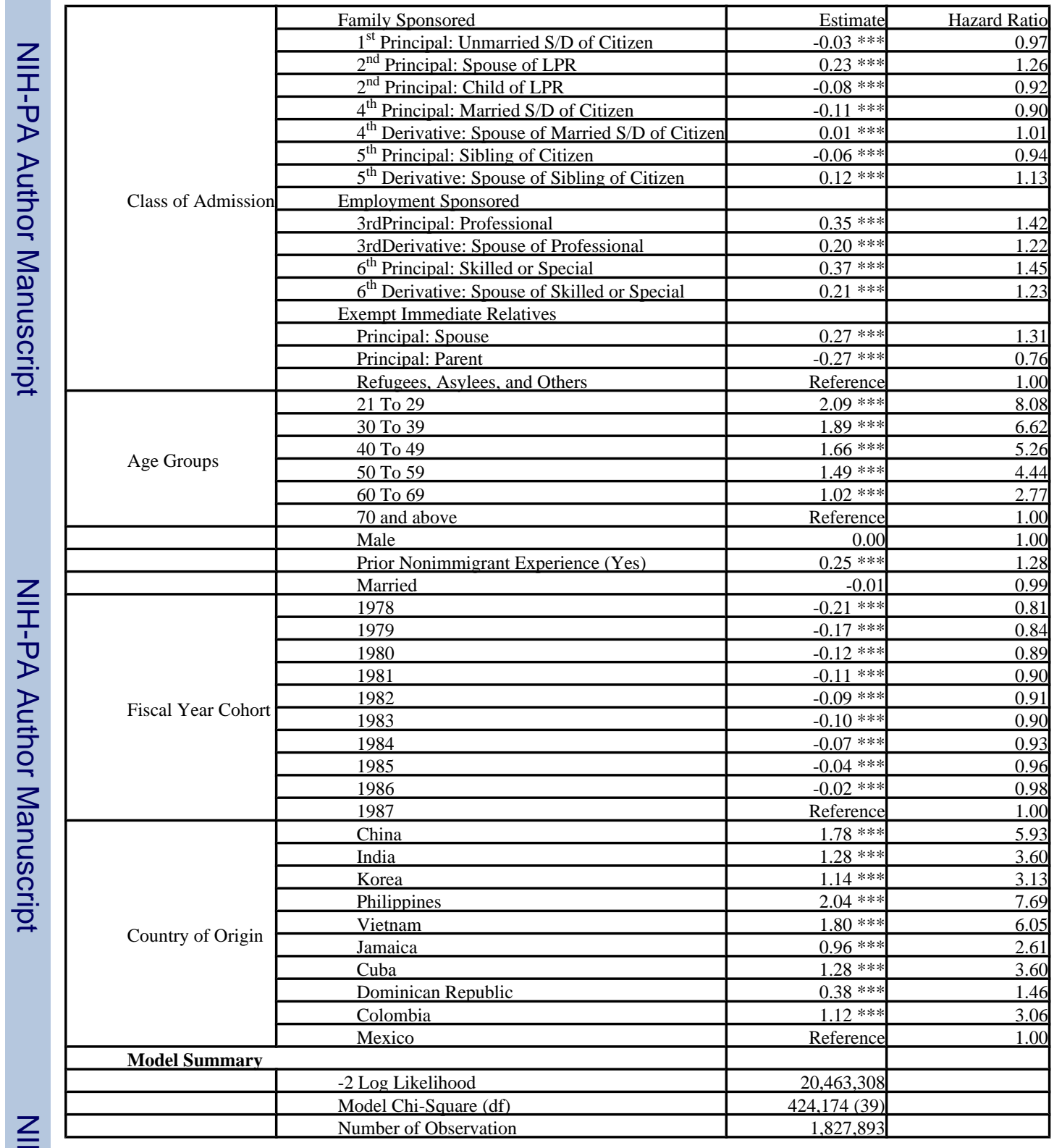

